\title{
Unlocking the potential of party research: Bringing sociology back in
}

Leopold Ringel, Lecturer, Faculty of Sociology, Bielefeld University; Jan Schank, Research Fellow, Centre for Security and Society, University of Freiburg; Damien Krichewsky, Lecturer, Forum Internationale Wissenschaft, University of Bonn and Jenni Brichzin, Research Fellow, Institute of Sociology, Chemnitz University

Research on political parties is a rich field, its origins dating back more than a century. Sociology played a crucial role in the foundation of party research. However, while party research has narrowed its scope and agenda, thus overlooking significant contributions from sociology, sociology has neglected the significance of political parties in the study of related social phenomena. To address this mismatch, the article explores how a sociological outlook on political parties can open up new research questions by conceptualizing political parties as embedded in societal processes, by accounting for various informal processes in party organizations, and by investigating the political profession with a comprehensive practice-based lens.

Introduction

Ever since Robert Michels seminal study on the German Social Democratic Party (Michels 1962 [1911]) and Max Weber's influential essay on politics as a profession (Weber 2004 [1919]), political parties have been a popular subject of research in the social sciences. As a result, party scholars have produced a considerable body of research over the past decades. However, while the first canonical publications in this research field were authored by sociologists, the study of political parties has ever since been dominated by political science. Undoubtedly, party research has provided significant insights into the functioning and inner life of political parties. It has extensively reflected on their diverse functions throughout the political process, from the facilitation of social choice (Hershey 2006) to the recruitment of political personnel (Norris 2006); it has examined how party formation and party structures change over time (Krouwel 2006); and it closely monitors current developments in party membership (Mair and van Biezen 2001). In contrast, sociology arguably moved to the margins of the field of party research, focusing instead on political phenomena such as social movements, ideologies, or political action in everyday life, extending beyond the classical political institutions of the state. 
The article argues that the relative neglect of sociological perspectives by party research, and, in turn, sociology's neglect of parties as a topic of research comes with a price attached. Our main point which we are going to elaborate in the following sections is that the 'sociological gaze' equips party researchers with conceptual tools allowing an analytical distance from mundane problems and assumptions about the nature of empirical phenomena. In so doing, we outline and emphasize themes that point to subtle, yet powerful dynamics at play. Of course, the point is not to pit sociology against political science, and vice versa, but to draw attention on the analytical potential of sociology for enriching the study of political parties.

For heuristic purposes, the article discusses conventional party research and our suggestions for new avenues of research at the macro-, meso-, and micro-level, as this is one common way to provide an overview of large bodies of literature in the social sciences. We emphasize the usage of the plural: the point is not to promote or favor a specific sociological theory, but to discuss a multiplicity of theories, concepts, and epistemologies, which, each in their own way, have the potential to enrich and further develop party research.

\section{Sociology and political science: Siamese twins or awkward couple?}

The endeavor of reintroducing sociology to a research field dominated by political science requires a few preliminary remarks on the boundary between these two disciplines. Setting aside the sensitive nature of boundary-making, which necessarily touches upon academic identities, it is not easy to disentangle the two. In fact, sociology and political science have much in common. They share common roots, which can be found for instance in the classical works of Max Weber, or Karl Marx. Their fields of inquiry overlap considerably, in particular in the case of political sociology (Sartori 1969). Making references across this disciplinary boundary is also a common practice. And many sociologists and political scientists have educational backgrounds and/or academic profiles which entail some elements coming from the other side. Furthermore, are the two disciplines not too differentiated internally to speak of the sociological in contrast to the political science approach?

Notwithstanding these entanglements, sociology and political science are not only distinct at the level of formal academic institutions. They have also developed distinct traditions, bodies of literature, and research questions. In particular, as pointed out by Niklas Luhmann (2000a), they tend to maintain different epistemological relations to their object of inquiry. While political science often takes assumptions and problems prevailing in the political field as a point of departure for its own investigations, sociology tends to take a step back and bracket these assumptions and problems. For instance, political science tends to study political institutions in a way that adopts and sometime even promotes the normative premises of liberal democracy (Brichzin et al. 2018). The participation of citizens in political processes is assumed to be desirable; the erosion of trust in democratic 
institutions is considered a problem to be solved - including through inputs from political science; the ongoing surge of right-wing populist movements and parties is envisaged as an indicator of political crisis; and so on. While, as individuals, the majority of political scientists and sociologists probably share a preference for democratic regimes, this close epistemological relation of political science with the political field narrows its scope to a view derived from the status quo of political reality. This comes at the cost of research questions transcending this status quo - an issue especially problematic in times of profound social and political change.

By contrast, sociology, at its core, pursues the study of the sociohistoric genesis, stabilization, and change of all societal values, norms, and roles which have become "naturalized' over time, and which therefore often escape our scholarly attention as potential objects of research. As Georg Simmel (1910) argued, the discipline's primary task is to investigate "how is society possible", i.e. to unveil the tacit but powerful social fabric underlying our daily lives. This specific mode of observation transforms "socially insignificant objects into scientific objects" and, in turn, investigates even "a major socially significant object from an unexpected angle" (Bourdieu and Wacquant 1992, 221).

While political science's concerns for the health of liberal democracies is in tune with widespread popular concerns, the question of "how is society possible" is quite alien to mundane reasoning precisely because it derives "from an unexpected angle". However, we maintain that this emancipation from common assumptions and problems is an elementary feature of sociological inquiry as it allows scholarship to transcend societal preframings. Following Pierre Bourdieu, such emancipation is all the more necessary as the social sciences are "always prone to receive from the social world [they study] the issues that [they pose] about that world. Each society, at each moment, elaborates a body of social problems taken to be legitimate, worthy of being debated, of being made public and sometimes officialized and, in a sense, guaranteed by the state." (Bourdieu and Wacquant 1992, 236).

From Bourdieu's perspective, then, many of the questions examined by party research derive from social problems defined and 'officialized' by powerful institutions such as the state and the broader public sphere. Conversely, as we will try to show, the sociological mode of observation can contribute theories and concepts that, each in their own way, might help advance party research in directions that break with the political common sense.

Research on political parties: the dominance of political science

Party research has unveiled a variety of important insights over the past decades, offering a better understanding of the nature of political parties. For heuristic reasons, we develop an account of the state of research that is based on the familiar distinction between the macro-, meso-, and micro-levels of society. While some studies focus on macro dynamics 
in the political system (macro), others investigate political parties as formal organizations (meso) and the preferences and opinions of party members and voters (micro).

\section{The political system}

Studies taking a macro perspective are typically concerned with inter-party competition, interactions of parties with other elements of the political system, and the functions they fulfill within the system (van Hecke et al. 2018). As we are going to demonstrate, party research has traditionally taken the normative foundations of democratic theory as selfevident, thereby emphasizing the role of parties in determining the outcomes of political decisions, ensuring adequate representation of citizens' interests and preferences, and allowing for the peaceful transfer of power and allocation of government offices.

The characteristics of party systems are typically deduced from different models of democracy (Katz 2007). This is complemented by a corresponding set of normative prescriptions on how many parties should exist and how they should relate to their members, officials, and the electorate, depending, again, on the theory of democracy taken as the point of departure. The relations between parties and political systems are thus commonly derived from the latter's legal and/or constitutional frameworks, which are seen as more or less conducive to the parties' ability to fulfill the functions attributed to them (Stokes 1999; Dalton et al. 2011).

Prescriptive statements derived from theories of democracy also come to the fore in contributions focusing on "the quality of democracy" as an outcome of different party systems (Wolinetz 2006). The historical emergence of different party systems is traced to national "electoral laws and cleavage structures" (Wolinetz 2006, 51) between different segments of a given political system. Studies thus examine not only relations between parties, but also between parties and "the state". Gauja (2016), for instance, explicitly connects both themes in a comparative analysis of electoral laws in common law democracies, inquiring how various legislative regimes regulate and uphold democratic politics. Similarly, Nassmacher (2009) and the volume edited by Falguera et al. (2014) discuss party financing and its regulation both as a major aspect of party-state relations and as an important determinant of the structural characteristics of party systems. The link between the legal regulation of parties and democratic theory also comes to the fore in Rashova and van Biezen (2014) who discuss the impact of party regulation on the legitimacy of parties and the political system.

These contributions have in common that they focus predominantly on legal frameworks and their impact on parties. Even when they acknowledge that regulation in and of itself is not sufficient (as in the case of Rashkova and van Biezen 2014), they argue for the implementation of 'better' or 'different' formal rules. References to influences beyond the reach of legislation and administration, such as cultural factors, embedded routines, or the practical exigencies of political action are however largely missing. Moreover, these studies usually operate on a national level of analysis, thereby neglecting or 
not adequately accounting for transnational dynamics. Even when comparisons are made, they are typically of a cross-national rather than a transnational character, treating nation states as coherent and unified analytical entities.

To summarize: research on parties and their relation to political systems has certainly provided important insights into the functions of parties in modern democracies and shed light on some of the conditions and mechanisms allowing them to fulfill their functions. However, the emphasis on formal rules and legal frameworks makes macrolevel party research oblivious to other contributing factors. As we will argue below, theories of society can help overcome this narrow focus on formal rules, legal frameworks, and the nation state as the nucleus of analysis.

\section{Party types}

Dating back to the early $20^{\text {th }}$ century, a large body of research has sought to improve and refine typologies of political parties. Such typologies are predominantly descriptive, and they focus on the formal structures of party organizations as well as their relationships with the environment. We summarize this research by discussing the four most popular models of parties, which vary in terms of formal organization, degree of centralization, dependency on and integration of members, as well as their relationship to the state: elite parties, mass parties, catch-all parties, and cartel parties. ${ }^{1}$

Elite parties were the typical form of party organization in the $19^{\text {th }}$ and early $20^{\text {th }}$ century, comprising of mostly noble and/or affluent individuals elected to parliament (Krouwel 2006). Such parties had very loose formal structure with almost no party organization outside of parliament, thus amounting to an agglomeration of local parties mostly dormant between elections. As the name indicates, members of such parties generally hailed from the socioeconomic elite and relied neither on state funding nor on the collection of membership fees. Even though elite parties offered different political visions, interparty competition remained weak as such parties simply had too many aligned interests and, as a result, had to deal with minimal political cleavages.

Mass parties differed from elite parties and increasingly challenged their dominance at the end of the $19^{\text {th }}$ and the early $20^{\text {th }}$ century (Duverger 1954). Such parties typically emerged outside of state structures, representing and mobilizing large segments of society hitherto neglected by the political system, particularly the working classes and minority religious denominations. In contrast to elite parties, mass parties were highly centralized organizations outside of parliament, with a clear ideological vision and central party offices basically dictating elected representatives how to vote. Due to their commitment to organizing and catering to a specific segment of society outside of the political system, mass parties relied on ancillary organizations and were highly dependent on

\footnotetext{
${ }^{1}$ The literature, of course, discusses more types of party organizations. However, these four are the most popular and clearly distinguishable.
} 
membership fees to finance their activities. Due to their foundation in a clear ideological vision, mass parties were in fierce competition with other parties, making compromises inside or outside of parliament unlikely.

After World War II, mass parties had to deal with a decrease of cleavages between segments of society and as a result felt compelled to appeal to a more diverse electorate. Catch-all parties share similarities with mass parties in that they rely on a strong party organization, but they differ in terms of ideological purity in order to bridge social, economic, and denominational cleavages (Kirchheimer 1966). In comparison, catch-all parties have an even stronger leadership and professional party organization and often pursue elaborate media strategies. Their activities are therefore capital-intensive, making them increasingly dependent on state subsidies. Due to their tight connection to the state and mission to attract diverse segments of society, catch-all parties have a bias toward centrism and show less principled opposition to political rivals than mass parties.

Cartel parties reinforce those trends that started with catch-all parties, particularly the coupling-turned-fusion of party and state. Elected office holders are thus mainly oriented towards maintaining executive power as their political survival becomes more and more contingent upon state resources (Katz and Mair 1995). The name cartel party derives from parties' disintegrating even further from civil society, forming an interparty cartel revolving around the distribution of state resources. The "colluding parties become agents of the state and employ the resources of the state to ensure their own collective survival" (Katz and Mair 1995, 5). Cartels therefore span multiple parties and tend to block all-too fierce inter-party competition as they rely upon many informal agreements and backroom negotiations between rivaling parties.

While party typologies are descriptive and usually lack references to sociological theories of society, the implicit meta-theory seems to be that the organizational structure of parties is a mere reflection of social structure (Wiesendahl 1998): elite parties reflect the structure of relatively stable class societies with limited voting rights, whereas mass parties are a consequence of more segments of society seeking the right to vote whilst being in fundamental opposition to other (economical or denominational) segments. Catch-all and cartel parties, then, seem to be the logical dominant model in times of decreasing class struggles and the blurring of boundaries between the different strata. This view is rooted in the (rather outdated) functionalist perspective of contingency theory, which dominated organizational research in the 1950s and 1960s. While contingency theory has been extensively criticized in organization theory and sociology (e.g. Aldrich 1979; Child 1972; Crozier and Friedberg 1980; Wiesendahl 1998), resulting in a steady decline in scholarly interest, party research, albeit not explicitly referring to contingency theory (for an exception see Panebianco 1988), seems to remain implicitly invested in its core epistemological and theoretical positions (Wiesendahl 2015). In effect, research fails to show interest in many characteristics of political parties as formal and informal organizations. 


\section{Party membership and voting decisions}

Overall, party research prefers rational choice theory when examining individual behavior, thereby building upon the homo oeconomicus model of individual decision-making. Voting decisions are thus explained by aggregating individual voters' demographic characteristics (Stonecash 2000) and ideological inclinations (Davis et al. 2019), and by identifying the latter's overlap with party platforms (Niedermayer and Hofrichter 2016; Van Assche et al. 2018). Research on party members also focuses on aggregate demographic characteristics, which are held to contain explanatory power regarding individual decisions (e.g., Gauja and Jackson 2015; Niedermayer 2018).

Party membership as well as voting decisions are often discussed in explicitly economic terms, identifying a "supply" of and a "demand" for party membership (van Haute 2011). Likewise, voting decisions are explained by referring to marketing concepts such as "branding" (e.g., Grimmer and Grube 2017), thus configuring voters as "consumers" of a service (representation or participation) provided by parties. Effects of communicative activities of parties' targeting "public opinion" are analyzed in similar terms, with public opinion being - often implicitly - conceptualized as an aggregate of individual attitudes (e.g., Slothuus 2015; De Vries and Solaz 2019). This line of research, then, assumes an economic rationale of exchange to undergird individual political choices, be it party membership or electoral decisions.

There is an ongoing debate as to what are the most important factors determining the issues invoked by parties when engaging in competition for voters. Why, these studies ask, do parties choose particular (types or dimensions of) issues over others, as discussed, for instance, in a recent special issue of Party Politics (Rovny and Whitefield 2019). Typically, issues seem to be divided into one of two binary classes: they are either economic or non-economic issues. The task for party research is to identify which of those two types of issues is most important for determining voting decisions. Again, the hypotheses suggested in this line of research overwhelmingly rely on the model of voters (and parties) as rational and goal-seeking actors, for instance when political communication in election campaigns is explained by strategic incentives for parties to prefer one issue over another (e.g., Pardos-Prado and Sagarzazu 2019; De Vries and Solaz 2019).

Besides voters and members of the party base, elected representatives are a third group closely examined by micro-level research on political parties. Studies use aggregated demographic characteristics and attitudes of individual representatives and compare them to those of the electorate in order to assess the extent to which the political system fulfills its representative function (Heidar and Wauters 2019). The findings, however, indicate a considerable and, to some degree, increasing gap between the attitudes and preferences of representatives and represented, for instance, when it comes to European Integration (Vogel and Göncz 2018).

In sum, micro-level party research unveils several dynamics, particularly the divergence between elected representatives and the citizenry. However, the examples discussed in this section showcase that this scholarship has often limited its scope, both 
conceptually and empirically: conceptually, studies tend to oversimplify the complexities and nuances of political processes due to the dominance of rational choice based models; empirically, they frequently prefer polling data and, as a result, do not trace activities, interactions, and practices in political contexts, as doing so would require the application of non-standardized research methods.

\section{Research on political parties: bringing sociology back in}

Having discussed some of the merits and limitations of conventional party research, this section outlines how sociological theories and concepts can be used to enrich and push this area of research further. In so doing, phenomena, problems, and research questions come to the fore that are in many ways alien to the common sense of party research: how do different conceptualizations of modern society mandate different ways of embedding parties and political processes? What can we see when we focus on organizational activities, particularly on tacit and informal processes? And finally, what do politicians do in their everyday work, and how does this relate to the outcome of political processes? It is important to note that we draw from a variety of sociological theories, grounded in sometimes mutually exclusive methodological and epistemological positions, thereby benefitting from the discipline's multi-paradigmatic nature. We thus do not claim to present an integrated and overarching framework but argue for making greater use of sociological theories as heuristics that help make sense of particular empirical settings.

\section{The political system and society}

Various sociological theories conceptualize politics beyond the boundaries set by party research. We discuss three influential theories, world polity theory, social systems theory, and field theory, as they suggest unique interpretations of political processes by contextualizing the political system within a broader theory of transnational or world society. Doing so allows us to overcome the emphasis on formal rules, legal frameworks, and "methodological nationalism" (Wimmer and Schiller 2002), that is, an often-implicit bias directing researchers to conceptualize the nation-state as the dominant unit of analysis. Against this backdrop, we outline potential avenues for research, and, in consequence, shed new light on some of the premises limiting the scope of party research.

According to world polity theory in the institutional tradition, post-World War II society has increasingly been shaped by rationalized myths (Meyer and Rowan 1977) and what Meyer et al. (1997) call "world models". Such models prescribe universalized ideas of what individuals, organizations, and nation states are and the goals they should pursue. They are created and diffused by so-called rationalized others (Meyer 1996) or universalized third parties (Werron 2014), for example journalists, activists, international organizations, public intellectuals, and scientists. What makes these actors special is that the 
positions they promote in the public sphere are generally grounded in abstract values claiming universal validity, such as human rights, public health, saving the planet, or minority rights. As a result, modern world society is shaped by highly institutionalized ideas and ideals also pertaining to political actors and governing bodies. The latter are hence confronted with templates of how a proper and modern nation state ought to be - regardless of particular cultural, religious, or economic context. This explains, for instance, why many countries of the Global South create political institutions and adopt public policies which, upon closer inspection, are only loosely coupled with the way things actually work "on the ground" (e.g. Bradley and Ramirez 1996; Meyer 2000).

By emphasizing transnational mechanisms and processes of institutionalization, world polity theory draws attention to phenomena hitherto neglected by party research. It also allows for conceptualizing audiences - in this case: the electorate - not as a real group of people whose preferences and representation by politicians can be measured and assessed, but as a social construct manufactured in and by public statements of universalized third parties (Werron 2014; see also Brankovic, Ringel and Werron 2018). Against this backdrop, future studies could examine the following questions: How exactly are political parties and party systems shaped by rationalized myths (Pizzimenti and Calossi 2019)? What properties do rationalized/universalized others attribute to the electorate, and how do parties respond to such construction processes? And finally, how tightly or loosely coupled are party activities with "rationalized myths"?

In a similar vein, social systems theory conceives of modern society as an allencompassing - globalized - world society (Luhmann 2012). However, while world polity research argues that modern society is permeated by scientifically legitimized, universalized, and rationalized myths, Luhmann conceptualizes modern society as differentiated in equally important functional systems, such as politics, law, the economy, science, education, health, or religion, each having its own unique organizing principle, called "code". For instance, the code dominating the political system is powerful/powerless, which in liberal democracies is recoded as government/opposition. Even though functional systems are interdependent and connected by multiple "structural couplings" (such as the coupling of politics and law by constitutions), each of these systems is operationally closed (self-referential) and preoccupied with its own reproduction, a process that Luhmann refers to as "autopoiesis". Without going into too much detail with this highly complex theory, we would like to stress that party research can benefit in multiple ways from using a systems theoretical lens. Of the manifold possibilities, we provide two potential avenues for future studies.

First, systems theory calls for attention to system-internal dynamics and ongoing efforts of functional systems to uphold their autonomy. By taking such an internal point of view, researchers can revisit their interpretation of activities that are usually considered immoral, harmful, and/or illegal by studying their latent function for system maintenance. For instance, applying Luhmann's concept of “useful illegality” (Luhmann 1964), Kusche (2014) argues that political clientelism can actually have a stabilizing and therefore crucial function for political systems. In a similar vein, studies taking a systems theoretical 
perspective could investigate more thoroughly different kinds of activities, which at first sight might seem either inconspicuous or detrimental, but upon closer inspection help stabilizing and reproducing the autonomy of the political system. Second, in claiming that systems do not react directly to external stimuli, but only to internally constructed representations of their environment, systems theory bypasses the normative stance of democratic theory that the political system needs to adequately "represent the citizenry" (Krichewsky, forthcoming). Rather, we might ask how political parties shape - and thereby construct - internal representations of the environment of the political system, which extends much beyond the alleged interests and preferences of citizens.

Bourdieusian field theory offers yet another set of strategies to contextualize political parties and political processes in a novel way. Similar to Luhmann, Pierre Bourdieu sees the differentiation of modern society into an increasing number of autonomous spheres - fields - as its defining characteristic. However, there are also substantial differences. First, while Luhmann is preoccupied with identifying the functional aspects of systems, Bourdieu emphasizes struggles, hierarchies, and the constant exertion of symbolic power (Bourdieu and Wacquant 1992). Accordingly, "a field is a field of forces within which the agents occupy positions that statistically determine the positions they take with respect to the field, these position-takings being aimed either at conserving or transforming the structure of relations of forces that is constitutive of the field" (Bourdieu, 2005, 30). Second, unlike Luhmann's operationally-closed systems, fields typically have degrees of autonomy: The so-called heteronomous pole has sometimes considerable external dependencies such as economic constraints imposed by resourceful actors or by markets; the autonomous pole on the other hand can only be explained by reconstructing the field-internal logic pursued by actors. When discussing struggles between groups of actors, Bourdieu distinguishes between those pertaining to the "power to impose the dominant vision of the field" (in the case of the political field: rich/poor, citizen/foreigner) and the fact that even "the most irreducible adversaries [...] accept a certain number of presuppositions that are constitutive of the very functioning of the field." To theorize such deeply held beliefs, Bourdieu refers to what he calls "nomos" (Bourdieu 2000), that is, a field's "constitution", its "fundamental law" (Bourdieu 2000, 101), defining the stakes and legitimate practices.

According to Bourdieu (2005), the boundaries of the political field are relatively loose as journalists and social scientists, albeit participating in other fields, are in constant dialogue with politicians, vying for advantage, and trying to impose their unique interpretation of the world. He therefore sensitizes studies for exchange relations and struggles between the political field and adjacent fields. Second, drawing on the "nomos" concept, we might argue that no matter what the party affiliation, all professional members of the field implicitly accept certain rules of behavior, for example, respecting the privacy conditions of backroom negotiations and concepts of professionalism (Ringel 2017). As for the latter, Bourdieu argues that regardless of party affiliation, politicians see themselves as experts who - despite all public commitments to the 'wisdom of the crowd' and 'being a humble public servant' - know best what to do. Future studies might thus examine tacit 
rules and concepts upon which political debate unfolds as they moderate and thus help explain even the fiercest of conflicts. And third, considering the connection of fields at different levels, studies might also examine if and how global fields impact national political fields and vice versa (Buchholz 2016).

\section{Parties as ecosystems of formal and informal behavior}

While typologies of conventional party research usually emphasize the formal characteristics of political parties and seem to rest implicitly on contingency theory, a variety of organizational approaches has shed light on aspects that are of a more informal nature and emphasize intra-organizational processes, thus overcoming the notion of party structure merely reflecting society's structure. In what follows, we are going to discuss three approaches that, each in their own way, challenge the tenets of party research and push scholarship in new directions: Micro politics, Goffman's frontstage/backstage model, and, again, systems theory.

Building on the theory of micro politics, Wiesendahl (1998) suggests viewing political parties as arenas in which heterogeneous types of individual actors vie for advantage (Burns 1961; Crozier and Friedberg 1980). Scholars drawing from a micro politics perspective reject visions of organizations as unitary and rational actors. Instead they highlight strategic actions of interdependent individuals and groups, who are constantly engaged in subtle games of cooperation and conflict within and across the boundaries of formal organizations. As a result, actors frequently deviate from formalized goals and rules. Wiesendahl outlines a typology of groups of actors within parties (traditional party members, careerists, policy activists, lobbyists), who apply a variety resources such as formal positions, internal networks, expertise, or contacts to powerful external actors to construct different visions, which they try to impose as the dominant vision within the party organization. Conceptualizing parties as arenas of contentious interaction sensitizes for the ubiquity of internal power plays involving different types of resources (e.g. information, expertise, networks) and cautions against the common sense of party research according to which organizational structures are determined by external conditions. In contrast, whatever the structure of a party, from a micro-political perspective, it is the result of intra-organizational struggles and coalition building. Crozier and Friedberg (1980) emphasize that it is never one group that has all the power while other groups possess none; rather, even those who seem dominated control some sort of resource, which they use strategically in negotiations. A micro-political framework thus suggests studying in-depth processes within party organizations, to investigate different types of resources that actors apply in strategic actions and calls for a case study design.

For the most part, party scholarship tends to frown upon political secrecy, branding it as horse-trading and dubious backroom negotiations both of which it considers detrimental to the democratic process. A sociological take, however, calls for more nuance. In their seminal works, Simmel (1906) and Goffman (1959) offer alternative views, 
analyzing the positive functions of secrecy in everyday life and refraining from making it a moral issue. While Simmel makes historical observations and draws attention to the formation of new types of secrecy in reaction to disclosure practices, Goffman discusses the importance of so-called "backstages", where individuals can prepare their public selfpresentations on the "frontstage". Both types of situations are separated but at the same time intertwined: public self-presentations rely on the ability of individuals to deviate from norms endorsed in the frontstage in other, more private, situations.

Drawing on both Goffman and Simmel, Ringel $(2017,2019)$ argues that, just like individuals, organizations, too, have to separate frontstages and backstages in order be considered legitimate, which stands in direct opposition to frequent calls for more transparency. Accordingly, measures to increase transparency are likely to trigger the emergence of new forms of secrecy, thus shifting respective front- and backstage arrangements. Organizations facing such demands provide their members with elaborate "fronts, appearances, manner, routines" (Manning, 2008, 680) to maintain an idealized "presentation of the system for nonmembers" (Luhmann 1964, 108. Our translation). Empirically, Ringel studies the Pirate Party of Germany, a party made up of firm believers in extensive forms of government transparency, which they vowed to implement. When elected into four state parliaments, the Pirates tried to put their vision into practice by enacting comprehensive forms of transparency. After running into manifold problems and creating a negative public perception, they established a working relationship with political opponents in the state parliament and put safeguards into place to avoid scandalizations by the media. The case demonstrates that even an organization with members who are totally committed to transparency eventually runs into different kinds of problems, which, at a general level, demonstrates limitations of engendering comprehensive transparency. Studies could use this framework to examine a variety of questions, for example the impact of digitalization on parties' efforts to manage visibility both online and offline (see also Gerbaudo 2019; Laube et al. 2017), or how parties react to PR-crises often caused by breaches between front- and backstages. Again, we emphasize that sociological perspectives can help scholars to critically examine and revisit everyday assumptions in this case the supposedly 'good' effects of organizational transparency and the 'bad' nature of practices of secrecy.

Having outlined how systems theory can contribute important insights on the relationship between party politics and society, we argue that it also harbors significant analytical potential for the study of parties as organizations (Luhmann 2000a, 2000b; Siri 2012). Again, the concepts of autopoietic self-reproduction and autonomy are particularly illuminating. Even though organizations are established to fulfill certain goals - in the case of parties: implementing political programs based on particular visions and ideals once they exist, they develop a life of their own independent of the original vision as they are primarily occupied with their own reproduction. From a Luhmannian perspective, it follows that parties essentially become "career organizations" primarily concerned with internal processes (Reese-Schäfer 2002). In terms of self-reproduction, Luhmann argues that organizations are a specific type of system that is based on the constant production 
and interlinking of decisions. They are, in Nassehi's (2005) words, "decision machines". Luhmann distinguishes between decisions mandated by the formal structure (decided decision-premises) and those connected to the informal structure (undecided decision-premises).

Both, the autopoietic self-reproduction of organizations as well as the theory of decision-premises, offer innovative avenues for research. While studies often criticize the lack of interest for pressing social problems displayed by parties, systems theory allows to turn conventional wisdom upside down: a significant decoupling of parties from problems experienced and formulated in their societal surrounding is a necessary condition of their organizational existence. In this perspective, party research could examine how organizational features of parties (their decision-premises) condition their selective sensitivity to internal representations of external problems and demands. More generally, focusing on the interlinking of decisions and decision-premises, studies could further investigate how formal (decided) and emergent (undecided) orders interact in party organizations.

\section{Practice-based approaches}

While conventional micro-level party research prefers rational choice-based models, relies mostly on polling data, and emphasizes people's preferences and opinions, recent developments in sociology draw attention to other concepts of social action and to other types of data. We particularly highlight two turns that help redirecting research at the micro-level: from opinions and preferences to practices (practice turn), and from a focus on the social and thus the idealistic or cognitive sphere to an appreciation of materiality (material turn).

Compared to rational choice-based models of action, practice-based research in sociology suggests significant conceptual and epistemological shifts. Instead of taking the logic of (economic) rationality for granted, practice theory starts from the contrary viewpoint on human action as open and indeterminable (Bourdieu 1977). Viewed from a practice-based lens, coping with complex social circumstances is an accomplishment of situated and embodied (inter-)action resulting in a certain practical logic that is likely to differ widely from one context to another. Thus, it is an empirical task to decipher the different logics of action in different contexts - which explains the inclination of practice research toward non-standardized, qualitative research methods, especially the careful and detailed reconstruction of interactive sequences in the course of in-depth ethnographic research.

In the field of politics, the practice-based lens raises a variety of questions as it departs from conceptualizations of political action as power-oriented, opportunistic, and calculated, and calls for in-depth ethnographic research on local party groups, board meetings, election campaigns, general assemblies etc. Recently, several studies (Laube 2018; Scheffer 2014; Brichzin forthcoming) examined the practical problems that MPs have to 
deal with in their everyday life in parliament such as: what is political action directed at? How do collective positions (of a parliamentary group, or, indeed, an entire party) as well as forceful ideas come about? Are there different logics of political practice? These studies have demonstrated that practice-based research on parliamentary processes can contribute to our understanding of how and why normative claims about representative democracies do not account for the full story. They showcase that parliamentary groups devote much of their energy to generating unified, coherent, and, distinctive collective positions, which cannot simply be viewed as mere "representations" (Laube et al. 2017; Laube et al., forthcoming). Researchers may well be justified in identifying "representation," "responsiveness", and other abstract values as the outcomes of these distributed work processes; they are, however, not necessarily the main goals of the actors involved in their creation. Studies also indicate that rational-choice-based models are unable to account for the complexities, nuances, and ambivalence of parliamentary practice. Brichzin (forthcoming), for example, analyses three modes of political practice in parliament - "political game", "political composition", "settling of issues". Only one of these modes ("political game") is connected to the party logic and to the reelection motive.

While practice theory in political research already takes the material dimension into account - i.e. the impact of bodily presence, or of the material infrastructure (e.g. clocks or digital devices) -, the material turn goes one step further: materiality is not only an important factor among others, but a genuine quality of the social itself. The importance of materiality had long been neglected in sociology, with Emil Durkheim and Max Weber famously banning all things non-social from sociological inquiry. Over the past decades, however, matter has become an important and extensively theorized topic (Clegg and Kornberger 2006; Dale and Burrell 2008; Latour 2005), the relevance of which for understanding political processes has only been discovered recently (Barry 2013; Marres 2012). Material approaches to politics make two crucial points. On the one hand, materiality - i.e. infrastructure, technology, architecture - is indispensable for the alignment of political action, especially in complex political systems. For instance, Laube (2018) shows how the digital infrastructure used by a parliamentary group allows for organizing public communication during an election campaign. In a similar vein, Husted and Plesner (2017) examine the construction of physical and digital space, which enables the participation of citizens in political decision processes, referred to by the authors as open-source politics. Dányi (2018) argues that architectural configurations as well as their history are an important factor in explaining political processes in parliaments. On the other hand, material objects themselves often become instigators of political processes. They are, in other words, actors of their own accord insofar as their qualities and appearances evoke and direct political reactions. Barry (2013), for example, examines the political consequences of the construction of an oil pipeline, which reach far beyond political institutions. Asdal and Hobæk (2016) trace the path of a whale through parliament. These examples demonstrate that there are good reasons to believe that recognizing the material dimension of political work helps to further our understanding of parties, drawing attention to how "things" act and influence political processes. 
In sum, we suggest extending and redirecting the focus of party research at the micro, meso, and macro-level by drawing from a multiplicity of sociological theories and concepts:

\begin{tabular}{|l|l|l|l|}
\hline & Macro-level & Meso-level & Micro-level \\
\hline $\begin{array}{l}\text { Conven- } \\
\text { tional party } \\
\text { research }\end{array}$ & $\begin{array}{l}\text { Focussing on the } \\
\text { functions of political } \\
\text { parties for the polit- } \\
\text { ical system }\end{array}$ & $\begin{array}{l}\text { Focussing on devel- } \\
\text { oping typologies of } \\
\text { political parties }\end{array}$ & $\begin{array}{l}\text { Focussing on individu- } \\
\text { als: members of the po- } \\
\text { litical parties, and the } \\
\text { voters of political par- } \\
\text { ties }\end{array}$ \\
\hline $\begin{array}{l}\text { Bringing } \\
\text { sociology } \\
\text { back in }\end{array}$ & $\begin{array}{l}\text { Focussing on the re- } \\
\text { lationship of politi- } \\
\text { cal parties and soci- } \\
\text { ety }\end{array}$ & $\begin{array}{l}\text { Focussing on political } \\
\text { parties as formal and } \\
\text { informal organizations }\end{array}$ & $\begin{array}{l}\text { Focussing on diverse } \\
\text { (and material) forms of } \\
\text { practice in political par- } \\
\text { ties }\end{array}$ \\
\hline
\end{tabular}

\section{Conclusion}

Despite all epistemological, methodological, and even paradigmatic differences, sociological theories, at their core, are invested in gaining a deeper understanding of the tacit yet powerful dynamics that steer our everyday lives. Each in their own way, they address the Simmelian question "how is society possible?" by examining the genesis, stabilization, and change of social phenomena. In contrast to party research in the political science tradition, sociology thus draws attention to the importance of remaining heedful to the pitfalls of accepting problems pre-defined by society, usually in the guise of social problems. This does not mean that sociology cannot not be critical, quite the contrary. However, criticism should derive from studies undertaken according to sociologically and not socially defined problems.

Research on political phenomena is particularly prone to accept social problems as scientific problems. An influential and powerful host of institutions such as the state, political parties, think tanks, the media, but also activists and what is usually referred to as civil society are deeply invested in defining problems and questions worthy of scientific inquiry. This is not to say that such problems and questions are not worthy of pursuing; however, as we hope to have demonstrated in the course of this article, there is an array of highly relevant avenues of research that has yet to be discovered by party research. By shifting the attention from the legal framework of the political system to dynamics beyond the boundaries of nation states, from the formal scaffolding of party organizations to informal processes, and from rational-choice-based theories of individual preferences to everyday practices and the material dimension, we hope to contribute to unlocking sociology's potential for party research. 
References

Aldrich, H. E. (1979). Organizations and environments. Englewood Cliffs: Prentice Hall. Asdal, K. and Hobæk, B. (2016). Assembling the Whale: Parliaments in the Politics of Nature. Science as Culture, vol. 25(1), pp. 96-116. https://doi.org/10.1080/ 09505431.2015.1093744

Barry, A. (2013). Materialist Politics: Disputes along the pipeline. Chichester: WileyBlackwell.

Bourdieu, P. (1977). Outline of a theory of practice. Cambridge: Cambridge University Press. https://doi.org/10.1017/CBO9780511812507

Bourdieu, P. (2000). Pascalian meditations. Stanford: Stanford University Press.

Bourdieu, P. (2005). The Political Field, The Social Science Field, and Journalistic Field. In: R. Benson and E. Neveu, eds., Bourdieu and the Journalistic Field, $1^{\text {st }}$ ed. Cambridge: Polity Press, pp. 29-47.

Bourdieu, P. and Wacquant, L. (1992). An invitation to reflexive sociology. Cambridge: University of Chicago Press.

Bradley, K. and Ramirez, F. (1996). World Polity Promotion of Gender Parity: Women's Share of Higher Education, 1965-85, Research in Sociology of Education and Socialization, vol. 11, pp. 63-91.

Brankovic, J., Ringel, L. and Werron, T. (2018). How rankings produce competition: The case of global university rankings. Zeitschrift für Soziologie, vol. 47(4), pp. 270288. https://doi.org/10.1515/zfsoz-2018-0118

Brichzin, J. (forthcoming). Materialisations from Political Work. In: E. Dányi, ed., Social Studies of Science, Special Issue.

Brichzin, J., Krichewsky, D., Ringel, L., and Schank, J. (2018). Soziologie der Parlamente. Konturen eines Programms. In: J. Brichzin, D. Krichewsky, L. Ringel and J. Schank, eds., Soziologie der Parlamente. Neue Wege der politischen Institutionenforschung, $1^{\text {st }}$ ed. Wiesbaden: Springer VS, pp. 1-32. https://doi.org/ 10. 1007/978-3-658-19945-6

Buchholz, L. (2016). What is a global field? Theorizing fields beyond the nation-state. The Sociological Review Monographs, vol. 64, pp. 31-60. https://doi.org/10. 1002/2059-7932.12001

Burns, T. (1961). Micropolitics: Mechanisms of institutional change. Administrative Science Quarterly, vol. 6(3), pp. 257-281. https://doi.org/10.2307/2390703

Child, J. (1972). Organizational Structure, Environment and Performance: The Role of Strategic Choice. Sociology, vol. 6, pp. 1-22. https://doi.org/10.1177/ 003803857200600101

Clegg, S. R. and Kornberger, M. (eds.) (2006). Space, Organizations and Management Theory. Frederiksberg: Liber and Copenhagen Business School Press.

Crozier, M. and Friedberg, E. (1980). Actors and systems. The politics of collective action. Chicago, IL: University of Chicago Press. 
Dale, K. and Burrell, G. (2008). The Spaces of Organisation and the Organisation of Space: Power, Identity and Materiality at Work. Basingstoke: Palgrave Macmillan.

Dalton, R. J., Farrell, D. M. and McAllister, I. (2011). Political Parties and Democratic Linkage. How Parties Organize Democracy. Oxford: Oxford University Press. https://doi.org/10.1093/acprof:osobl/9780199599356.001.0001

Dányi, E. (2018). The things of the parliament. In: J. Brichzin, D. Krichewsky, L. Ringel and J. Schank, eds., Soziologie der Parlamente. Neue Wege der politischen Institutionenforschung, $1^{\text {st }}$ ed. Wiesbaden: Springer VS, pp. 267-285. https://doi.org/ 10.1007/978-3-658-19945-6

Davis, N. T., Goidel, K., Lipsmeyer, C., Whitten, G. D. and Young, C. (2019). The Political Consequences of Nativism: The Impact of Nativist Sentiment on Party Support. Social Science Quarterly, vol. 100(2), pp. 466-479. https://doi.org/10. 1111/ssqu. 12596

De Vries, C. E. and Solaz, H. (2019). Sweeping it under the rug: How government parties deal with deteriorating economic conditions. Party Politics, vol. 25(1), pp. 63-75. https://doi.org/10.1177/1354068818816967

Duverger, M. (1954). Political parties: their organization and activity in the modern state. London: Methuen.

Eldersveld, S. J. (1964). Political Parties: A Behavioral Analysis, Chicago: Rand McNally.

Falguera, E., Jones, S. and Ohman, M. (2014). Funding of Political Parties and Election Campaigns. A Handbook on Political Finance. Stockholm: International IDEA.

Goffman, E. (1959). The presentation of self in everyday life. New York: Anchor Books.

Gauja, A. (2016). Political Parties and Elections. Legislating for Representative Democracy. London: Routledge. https://doi.org/10.4324/9781315601205

Gauja, A. and Jackson, S. (2015). Australian Greens party members and supporters: their profiles and activities. Environmental Politics, vol. 25(2), pp. 359-379. https://doi.org/10.1080/09644016.2015.1104803

Gerbaudo, P. (2019). The digital party: political organisation and online democracy. London: Pluto Press.

Grimmer, M. and Grube, D. S. (2017). Political branding: A consumer perspective on Australian political parties. Party Politics, vol. 25(2), pp. 268-281. https://doi.org/10.1177\%2F1354068817710585

Heidar, K. and Wauters, B. (2019). Do Parties Still Represent? An Analysis of the Representativeness of Political Parties in Western Democracies. London: Routledge. https://doi.org/10.4324/9781351110952

Hershey, M. (2006). Political parties as mechanisms of social choice. In: R. S. Katz and W. J. Crotty, eds., Handbook of party politics, $1^{\text {st }}$ ed. London: Sage, pp. 75-88. http://dx.doi.org/10.4135/9781848608047.n9 
Hopkin, J. and Paolucci, C. (1999). The business form model of party organization: cases from Spain and Italy. European Journal of Political Research, vol. 35, pp. 307339. https://doi.org/10.1023/A:1006903925012

Husted, E. and Plesner, U. (2017). Spaces of open-source politics: Physical and digital conditions for political organization. Organization, vol. 24(5), pp. 648-670. https://doi.org/10.1177/1350508417713215

Katz, R. S. (2007 [1980]). A Theory of Parties and Electoral Systems. Baltimore: Johns Hopkins University Press.

Katz, R. S. and Mair, P. (1995). Changing models of party organization and party democracy: the emergence of the cartel party. Party Politics, vol. 1, pp. 5-28. https://doi.org/10.1177/1354068895001001001

Katz, R. S. and Crotty, W. J. (2006). Handbook of Party Politics. London: Sage.

Kirchheimer, O. (1966). The transformation of Western European party systems. In: J. LaPalombara and M. Weiner, eds., Political parties and political development, $1^{\text {st }}$ ed. Princeton: Princeton University Press, pp. 177-200.

Krichewsky, D. (forthcoming). Political Responsiveness: The Identification and Processing of Problems in Modern Polities. In: A. L. Ahlers, D. Krichewsky, E. Moser and R. Stichweh, eds., Sociology of Contemporary Political Systems: Inclusion and Differentiation, $1^{\text {st }}$ ed. Bielefeld: Transcript.

Krouwel, A. (2006). Party models. In: R. S. Katz and W. J. Crotty, eds., Handbook of party politics, $1^{\text {st }}$ ed. London: Sage, pp. 249-269. http://dx.doi.org/10.4135/ 9781848608047.n22

Kusche, I. (2014). Political Clientelism and Democracy: Clientelistic power and the internal differentiation of the political system. Acta Sociologica, vol. 57(3), pp. 207221. https://doi.org/10.1177/0001699313506721

Laube, S. (2018). Unsichtbare Stützen des Politikbetriebs. Zu einer Soziologie politischer Wissenszuarbeit. In: J. Brichzin, D. Krichewsky, L. Ringel and J. Schank, eds., Soziologie der Parlamente. Neue Wege der politischen Institutionenforschung, $1^{\text {st }}$ ed. Wiesbaden: Springer VS, pp. 209-230.

Laube, S., Schank, J. and Scheffer, T. (2017). Work-in-progress. Medien als Status-Marker in der Fertigung politischer Positionen. In: F. Krotz, C. Despotovic and C. C. Kruse, eds., Mediatisierung als Metaprozess. Transformationen, Formen der Entwicklung und die Generierung von Neuem, $1^{\text {st }}$ ed. Wiesbaden: Springer VS, pp. 113-135.

Laube, S., Schank, J. and Scheffer, T. (forthcoming). Constitutive Invisibility. Exploring the Work of Staff Advisers in Political Position Making. Social Studies of Science.

Latour, B. (2005). Reassembling the Social. Oxford: Oxford University Press.

Lowenstein, D. H. (2006). Legal regulation and protection of American parties. In: R. S. Katz and W. J. Crotty, eds., Handbook of Party Politics, $1^{\text {st }}$ ed. London: Sage, pp. 465-470.

Luhmann, N. (1964). Funktionen und Folgen formaler Organisation. Berlin: Dunker and Humblot. 
Luhmann, N. (2000a). Die Politik der Gesellschaft. Frankfurt am Main: Suhrkamp.

Luhmann, N. (2000b). Organisation und Entscheidung. Opladen: Westdeutscher Verlag. Luhmann, N. (2012). Theory of society, Volume 1. Stanford: Stanford University Press.

Marres N. (2012). Material Participation. Technology, the Environment and Everyday Publics. Basingstoke: Palgrave Macmillan.

Mair, P. and van Biezen, I. (2001). Party Membership in Twenty European Democracies, 1980-2000. Party Politics, vol. 7(1), pp. 5-21. https://doi.org/10.1177/ 1354068801007001001

Manning, P. (2008). Goffman on organizations. Organization Studies, vol. 29(5), pp. 677699. https://doi.org/10.1177/0170840608088767

Meyer, J. W. (1996). Otherhood. The promulgation and transmission of ideas in the modern organizational environment. In: B. Czarniawska and G. Sevón, eds., Translating organizational change, $1^{\text {st }}$ ed. Berlin: de Gruyter, pp. 241-252.

Meyer, J. W. (2000). Globalization: Sources and Effects on National States and Societies. International Sociology, vol. 15(2), pp. 233-248. https://doi.org/10.1177/ 0268580900015002006

Meyer, J. W., Boli, J., Thomas, G. M. and Ramirez, F. O. (1997). World society and the nation-state. American Journal of Sociology, vol. 103(1), pp. 144-181.

Meyer, J. W. and Rowan, B. (1977). Institutionalized organizations: Formal structure as myth and ceremony. American Journal of Sociology, vol. 83(2), pp. 340-363.

Michels, R. (1962 [1911]). Political parties. New York: Collier Press.

Müller, W. C. and Sieberer, U. (2006). Party law. In: R. S. Katz and W. J. Crotty, eds., Handbook of Party Politics, $1^{\text {st }}$ ed. London: Sage, pp. 435-445.

Nassehi, A. (2005). Organizations as decision machines: Niklas Luhmann's theory of organized social systems. Sociological Review, vol. 53(1), pp. 178-191. https://doi.org/10.1111/j.1467-954X.2005.00549.x

Nassmacher, K. H. (2009). The Funding of Party Competition. Political Finance in 25 Democracies. Baden-Baden: Nomos.

Niedermayer, O. (2018). Parteimitglieder in Deutschland: Version 2018. Arbeitshefte aus dem Otto-Stammer-Zentrum, Nr. 29. Berlin: Freie Universität Berlin. http://dx.doi.org/10.17169/refubium-499

Niedermayer, O. and Hofrichter, J. (2016). Die Wählerschaft der AfD: Wer ist sie, woher kommt sie und wie weit rechts steht sie? Zeitschrift für Parlamentsfragen, vol. 47(2), pp. 267-285.

Norris, P. (2006). Recruitment. In: R. S. Katz and W. J. Crotty, eds., Handbook of party politics, $1^{\text {st }}$ ed. London: Sage, pp. 89-108. http://dx.doi.org/10.4135/ 9781848608047.n10

Panebianco, A. (1988). Political parties: organization and power. Worcester: Cambridge University Press.

Pardos-Prado, S. and Sagarzazu, I. (2019). Economic performance and center-periphery conflicts in party competition. Party Politics, vol. 25(1), pp. 50-62. https://doi.org/10.1177/1354068818816978 
Pizzimenti, E. and Calossi, E. (2019). The neglected variable. The coevolution of public administration and political parties in the UK and Italy (1950-2010). Italian Political Science Review/Rivista Italiana Di Scienza Politica, 1-18. https://doi.org /10.1017/ipo.2019.19

Rashkova, E. R. and van Biezen, I. (2014). A contested legitimacy: The paradoxes of legal regulation of political parties. International Political Science Review, vol. 35(3), pp. 265-274. https://doi.org/10.1177/0192512114533981

Reese-Schäfer, W. (2002). Parteien als politische Organisationen in Luhmanns Theorie des politischen Systems. In: K. U. Hellmann and R. Schmalz-Bruns, Theorie der Politik. Niklas Luhmanns politische Soziologie, $1^{\text {st }}$ ed. Frankfurt: Suhrkamp, pp. 109-131.

Ringel, L. (2017). Transparenz als Ideal und Organisationsproblem. Eine Studie am Beispiel der Piratenpartei Deutschland. Wiesbaden: Springer VS. https://doi.org/10. 1007/978-3-658-18328-8

Ringel, L. (2019). Unpacking the transparency-secrecy nexus. Frontstage and backstage behavior in a political party. Organization Studies, vol. 40(5), pp. 705-723. https://doi.org/10.1177/0170840618759817

Sartori, G. (1969). From the Sociology of Politics to Political Sociology. Government and Opposition, vol. 4(2), pp. 195-214. https://doi.org/10.1111/j.1477-7053.1969. tb00173.x

Scheffer, T. (2014). Die Arbeit an den Positionen - Zur Mikrofundierung von Politik in Abgeordnetenbüros des Deutschen Bundestages. Zeitschrift für Soziologie, special issue, pp. 369-389.

Simmel, G. (1906). The Sociology of Secrecy and of Secret Societies. American Journal of Sociology, vol. 11(4), pp. 441-498. https://doi.org/10.1086/211418

Simmel, G. (1910). How is Society Possible? American Journal of Sociology, vol. 16(3), pp. 372-391.

Siri, J. (2012). Parteien. Zur Soziologie einer politischen Form. Wiesbaden: Springer VS. https://doi.org/10.1007/978-3-531-18722-8

Slothuus, R. (2015). Assessing the Influence of Political Parties on Public Opinion: The Challenge from Pretreatment Effects. Political Communication, vol. 33(2), pp. 302-327. https://doi.org/10.1080/10584609.2015.1052892

Stokes, S. C. (1999). Political Parties and Democracy. Annual Review of Political Science, vol. 2, pp. 243-267. https://doi.org/10.1146/annurev.polisci.2.1.243

Stonecash, J. (2000). Class and Party in American Politics. New York: Routledge.

Van Assche, J., Van Hiel, A., Dhont, K. and Roets, A. (2018). Broadening the individual differences lens on party support and voting behaviour: Cynicism and prejudice as relevant attitudes referring to modern-day political alignments. European Journal of Social Psychology, vol. 49(1), pp. 190-199. https://doi.org/10.1002/ ejsp.2377

Van Haute, E. (ed.) (2011). Party Membership in Europe: Exploration into the anthills of party politics. Brussels: Editions de l'Université de Bruxelles. 
Van Hecke, S. et al. (2018). Reconnecting European Political Parties with European Union Citizens. International IDEA Discussion Paper 6/2018. Stockholm: International Institute for Democracy and Electoral Assistance. https://doi.org/10.31752/ idea.2018.71

Vogel, L. and Göncz, B. (2018). European Integration in the View of Political Elites and Citizens - An Increasing Gap? In: N. Conti, B. Göncz and J. Real-Dato, eds., National Political Elites, European Integration and the Eurozone Crisis, $1^{\text {st }} \mathrm{ed}$. London: Routledge, pp. 88-114.

Weber, M. (2004). The Vocation Lectures. Illinois: Hackett Books.

Werron, T. (2014). On public forms of competition. Cultural Studies $<=>$ Critical Methodologies, vol. 14(1), pp. 62-76. https://doi.org/10.1177/1532708613507891

Wiesendahl, E. (1998). Parteien in Perspektive: Theoretische Ansichten der Organisationswirklichkeit politischer Parteien. Opladen: Westdeutscher Verlag.

Wiesendahl, E. (2015). Noch auf der Höhe der Zeit? Die Parteienforschung im Epochenumbruch der Moderne. In: J. Krüper, H. Merten and T. Poguntke, eds., Parteienwissenschaft, $1^{\text {st }}$ ed. Baden-Baden: Nomos, pp. 161-184. https://doi.org/10. 5771/9783845257839

Willke, H. (1995). Systemtheorie III: Steuerungstheorie. Grundzüge einer Theorie der Steuerung komplexer Sozialsysteme. Stuttgart, Jena: Gustav Fischer Verlag.

Wimmer, A. and Glick-Schiller, N. (2002). Methodological nationalism and beyond: nation-state building, migration and the social sciences. Global Networks, vol. 2(4), pp. 301-334. https://doi.org/10.1111/1471-0374.00043

Wolinetz, S. (2006). Party systems and party system types. In: R. S. Katz and W. J. Crotty, eds., Handbook of party politics, $1^{\text {st }}$ ed. London: Sage, pp. 51-62. http://dx.doi.org/10.4135/9781848608047.n7 